\section{Chemical Tests for Vitamins}

At a meeting of the Society of Public Analysts on November 1, a discussion was held on "The Chemical (as distinct from Physiological) Tests for Vitamins". Mr. A. L. Bacharach, in opening the discassion, outlined the present state of knowledge of the chemistry of the individual vitamins, of which one, vitamin $\mathrm{C}$, has been synthesised. Of the others, most is known about the constitution of calciferol (vitamin D) and vitamin A. He enumerated such chemical tests as have been used or suggested for the estimation of vitamins, of which the two most important are the Tilmans-Harris test for ascorbic acid (vitamin $\mathrm{C}$ ) and the antimony trichloride test for vitamin A. Dr. Leslie Harris, discussing the most accurate methods of applying the antimony trichloride test for vitamin $\mathbf{A}$, said that for quantitative work it is essential to saponify the oil, substances interfering with the production of the blue colour being removed by hydrolysis. For vitamin $\mathrm{C}$ a quantitative method based on the use of Tillman's indophenol indicator has been made more nearly specific by a preliminary removal of interfering reducing substances. Prof. J. C. Drummond directed attention to certain defects in the B.P. procedure for the antimony trichloride test. The colours should be matched at the period of maximum intensity, and reliable results can only be obtained with the unsaponifiable matter. Mr. Norman Evers showed that even the blue value of the unsaponifiable matter of cod liver oil might not be the true vitamin value. He pleaded for uniformity in the method of expressing results. Mr. S. K. Crews and Mr. S. J. Cox read a paper on the relationship between the Carr-Price value and $328 \mathrm{~m} \mu$ absorption coefficient of preparations containing vitamin $\mathbf{A}$. They showed that the purification of vitamin A products removes substances which inhibit the blue colour and that eventually the ratio of the Carr-Price blue colour value to the ultraviolet absorption coefficient rises and tends to become constant.

\section{The Vitamin B Complex}

THE present position of research, both chemical and physiological, on the water-soluble B vitamins was outlined by Prof. R. A. Peters, Whitley professor of biochemistry in the University of Oxford, on November 3 at the twenty-third Bedson lecture delivered at Armstrong College, Newcastle upon Tyne. After alluding to the discovery of the vitamins, and the methods of biological assay employed, Prof. Peters sketched the processes used by van Veen, Ohdake, Windaus, and by his own co-workers for the isolation and purification of vitamin B, from rice polishings or yeast, including his own method of selective precipitation as phosphotungstate in solu. tions of varying $p H$ value, tracing the increase of activity in the concentrates, culminating in the various crystalline preparations of the workers mentioned above. $\mathrm{He}$ dealt then with the chemical analyses, $\mathrm{X}$-ray crystallographic, and absorption spectra studies of these substances, indicating how his material from yeast differed in activity, and also in carbon and sulphur content, from that prepared from rice polishings. Finally, Prof. Peters set out the evidence, often conflicting, for the elucidation of the chemical natures and biochemical rôles of the $B_{1}, B_{2}$ and $B_{4}$ factors in relation to the oxidation processes and enzyme systems of brain tissue.

\section{Association of Scientific Workers}

THe report of the Executive Committee presented on October 28 to the Council of the Association of Scientifie Workers is a doeument containing a record of sustained and useful work. The outstanding event of the last half-year has been the formation in conjunction with the British Science Guild of the Parliamentary Science Committee. The Association has also taken an active part, with other scientific bodies, in the endeavour to save the Research Association of British Rubber Manufacturers from disintegration. To that endeavour has been added an inquiry as to the best means of stabilising the finances of the industrial research associations generally. In this connexion, the Association has joined with the British Science Guild in the appointment of a joint committee; and when the labours of that body are completed it is probable that it will report to the Parliamentary Science Committee with the view of taking action. During the period under review, the University Degrees Bill, promoted by the Association, has received its second reading in the House of Lords without division; but it is not likely to reach the Statute Book before the session closes. A publication of which the Association may well be proud is "Science in Parliament", a summary of all affairs relating to science dealt with in Parliament. Another achievement has been the establishment of a publicity bureau.

\section{Sir Edward Frankland Memorials at Lancaster}

ON October 23 the Mayor of Lancaster (Mrs. A. E. Helme) opened the new technical workshops and craft rooms at Meeting House, and later formally opened the new Frankland Laboratory at the Storey Institute, Lancaster. The Laboratory, which will be devoted to chemistry, was founded in memory of the late Sir Edward Frankland, the eminent chemist. Frankland was born at Churchtown in Lancashire in 1825, but at an early age went to live in Lancaster. He studied chemistry under Playfair, Bunsen and Tyndall, and after carrying out some research under Liebig at Giessen, was elected professor of chemistry at Owens College, Manchester. Later he worked in London at St. Bartholomew's Hospital, the Royal Institution and at the School of Mines. $\mathrm{He}$ was elected a fellow of the Royal Society in 1853 and in 1894 he was awarded the Copley medal. On January 18, 1933, the anniversary of Frankland's birth, it was proposed to found a Frankland Society in Lancaster (see Nature of February 11, p. 197). The proposal was adopted and the Lancastrian Frankland Society came into being with Prof. H. E. Armstrong, Frankland's oldest living pupil, as president. The syllabus for the session 1933-34 of the new society has recently been issued. The meetings are to be held about once a month in the 